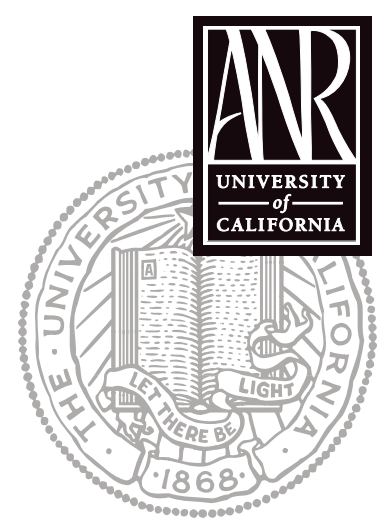

UNIVERSITY OF CALIFORNIA

Division of Agriculture and Natural Resources http://anrcatalog.ucdavis.edu

\title{
Genetic Engineering and Animal Feed
}

ALISON L. VAN EENENNAAM, Extension Specialist, Animal Genomics and Biotechnology, Department of Animal Science, University of California, Davis

In the United States, livestock have been fed genetically engineered crops since these crops were first introduced in 1996. In 2005, 87 percent of the U.S. soybean crop and 52 percent of the U.S. corn crop were grown from genetically engineered seed (see the USDA ERS Briefing Room Web site, http://www.ers.usda.gov/Data/BiotechCrops/ ExtentofAdoptionTable3.htm). Because the majority of corn (72\%) and soybeans $(60 \%)$ are used for livestock feed, it is clear that the livestock industry is a major user of genetically engineered crops.

\section{Are genetically engineered feeds safe for livestock?}

Over 100 digestion and feeding studies examining the effects of feeding genetically engineered crops to various food-producing animal species (e.g., beef cattle, swine, sheep, fish, lactating dairy cows, water buffalo, and chickens) have been reported in the scientific literature (see the Federation of Animal Science Societies Communications Web site at http://www.fass.org/references/Feeding_Transgenic_ Crops_to_Livestock.htm for a comprehensive listing by species and crop). Results have revealed no significant differences in the nutritional value of feedstuffs derived from commercially grown genetically engineered crops compared with their conventional counterparts, nor have any peer-reviewed studies documented alterations in feed intake, growth, or other livestock production parameters as a result of including currently available genetically engineered feedstuffs in diets of animals (for a comprehensive review, see Flachowsky et al. 2005). The published literature also contains no indication of any disturbance to food animal health or the quality of resulting animal products as a result of long-term consumption of genetically engineered feeds. Current scientific evidence confirms the concept of "substantial equivalence" for currently available genetically engineered feedstuffs. "Substantial equivalence" is a comparative approach to the assessment of food safety that involves comparing the feed value and safety of genetically engineered crops with those in existing crops (usually the genetically unmodified parent line) that have known feed values and a history of safe use.

\section{Does genetically engineered DNA or protein get into milk, meat, or eggs?}

Genetically engineered crops are digested by animals in the same way as conventional crops. Numerous scientific studies have examined the digestive fate of genetically engineered DNA and protein introduced into genetically engineered feed (see the Federation of Animal Science Societies Communications Web site, http://www.fass. org/references/Transgentic_DNA.htm, for a comprehensive listing). Genetically engineered DNA, or the novel proteins encoded therein, have never been detected in the milk, meat, or eggs derived from animals fed genetically engineered feedstuffs. Several studies have documented that small fragments of plant-derived, but not genetically engineered, DNA can pass into the tissues of animals that consume the plants (see, for example, Aumaitre et al. 2002). Multicopy plant-specific DNA sequences have been found in various tissues (e.g., muscle, spleen, liver, and kidneys) of chicken, cattle, and pigs. There has even been a report on the transient presence of rabbit DNA in blood samples derived from human volunteers after they ate a cooked rabbit meal (Forsman et al. 2003). The biological importance of these findings is unclear because 
the transient DNA fragments are generally too small to encode a protein, and it is unclear whether they possess any biological activity.

The presence of small DNA fragments derived from feed or food in animal tissues appears to be related, at least in part, to the amount of that DNA sequence in the diet. It has been estimated that when cows eat a feed ration containing 40 percent silage and 20 percent grain made from genetically engineered corn varieties, approximately 0.00042 percent of the animal's total daily DNA intake would consist of genetically engineered DNA (Beever and Kemp 2000). The fact that so little of the DNA consumed is genetically engineered, combined with the very low levels of even highly abundant plant-derived DNA fragments that have been found in animal products, may explain why genetically engineered DNA has never been detected in milk, meat, or eggs derived from animals fed genetically engineered feed. Given that this rare presence of plantderived DNA fragments in animal tissues appears to be a natural process, irrespective of genetically engineered feed consumption, coupled with the fact that there is no reason to suspect that genetically engineered DNA will behave any differently than other sources of DNA, it would seem to be only a matter of time until more sensitive assay systems are able to detect fragments of DNA derived from genetically engineered feed in tissues of animals that consume the DNA. However, there is also no reason to suspect that the biological significance of these DNA fragments will be any different than that associated with the DNA fragments that are derived from non-genetically engineered dietary sources.

\section{Are nutrients in the meat, milk or eggs different?}

Nutrients in meat, milk, and eggs from livestock fed genetically engineered feeds have been found to be the same as the nutrients from livestock fed conventional feeds. The metabolic processes involved in digestion, absorption, and use of feed proteins by livestock species make it very unlikely for a protein of any plant gene to be found intact in food of animal origin, and none have been detected. For this reason, products derived from animals that have been fed feedstuffs containing the current commercially approved genetically engineered crops do not require specific labeling in the United States. Labeling is required only when genetically engineered food products have a detectable difference in nutritional composition or safety when compared with comparable non-genetically engineered products. In addition, labeling that details the process(es) used to create compositionally equivalent food products is currently not required.

\section{What if I choose not to eat products from animals given genetically engineered feed?}

Consumers seeking to purchase products from animals that have not been fed genetically engineered feed can do so by purchasing organic livestock products. The USDA National Organic Program (http://www.ams.usda.gov/nop/NOP/NOPhome.html) requires that livestock sold, labeled, or represented as organic be fed organic feed sources only, unless organic feed sources are commercially unavailable. Even if organic livestock producers are statutorily permitted to use nonorganic feed sources for their livestock, the National Organic Program standards specifically prohibit the use of feed grains from genetically engineered sources.

\section{PERSPECTIVE}

Evidence to date strongly suggests that feeding livestock with genetically engineered crops is equivalent to feeding unmodified feed sources in terms of nutrient composition, digestibility, and feeding value. Over one hundred scientific studies have found no difference in the productive performance or health of livestock that have been fed 
genetically engineered feedstuffs, and they found no presence of genetically engineered DNA or proteins in the milk, meat, or eggs from animals that have eaten genetically engineered feed. Since it is not possible to distinguish any differences in the nutritional profile or components of animal products following inclusion of currently available genetically engineered feedstuffs in the animal diets, labeling of such animal products in not required in either the United States or Europe.

\section{REFERENCES}

Aumaitre, A., K. Aulrich, A. Chesson, G. Flachowsky, and G. Piva. 2002. New feeds from genetically modified plants: Substantial equivalence, nutritional equivalence, digestibility, and safety for animals and the food chain. Livestock Production Science 74:223-238.

Beever, D., and C. Kemp. 2000. Safety issues associated with the DNA in animal feed derived from genetically modified crops: A review of the scientific and regulatory procedures. Nutrition Abstracts and Reviews. Series B: Livestock Feeds and Feeding 70:175-182.

Federation of Animal Science Societies. 2005. Are the milk, meat, and eggs of livestock fed biotech crops safe to eat? FASS Web site, http://www.fass.org/geneticcrops.pdf.

- 2005. References: Feeding transgenic crops to livestock. FASS Web site, http://www.fass.org/references/Feeding_Transgenic_Crops_to_Livestock.htm.

- 2005. References pertaining to transgenic DNA and protein and livestock products (meat, milk, eggs). FASS Web site, http://www.fass.org/references/Transgentic_DNA.htm.

Flachowsky, G., A. Chesson, and K. Aulrich. 2005. Animal nutrition with feeds from genetically modified plants. Archives of Animal Nutrition 59:1-40.

Forsman, A., D. Ushameckis, A. Bindra, Z. Yun, and J. Blomberg. 2003. Uptake of amplifiable fragments of retrotransposon DNA from the human alimentary tract. Molecular Genetics and Genomics 270:362-368.

USDA Economic Research Service. 2005. USDA ERS Briefing Room Web site, "Adoption of Genetically Engineered Crops in the U.S., Soybeans," http://www.ers.usda.gov/Data/BiotechCrops/ExtentofAdoptionTable3.htm. Updated July 11, 2005.

USDA National Organic Program Web site, http://www.ams.usda.gov/nop/NOP/NOPhome.html. 


\section{FOR MORE INFORMATION}

To order or obtain printed ANR publications and other products, visit the ANR Communication Services online catalog at http://anrcatalog.ucdavis.edu. You can also place orders by mail, phone, or FAX, or request a printed catalog of our products from:

University of California

Agriculture and Natural Resources

Communication Services

6701 San Pablo Avenue, 2nd Floor

Oakland, California 94608-1239

Telephone: (800) 994-8849 or (510) 642-2431

FAX: (510) 643-5470

E-mail inquiries: danrcs@ucdavis.edu

An electronic version of this publication is available on the ANR Communication Services Web site at http://anrcatalog.ucdavis.edu.

\section{Publication 8183}

(C) 2005 by the Regents of the University of California, Division of Agriculture and Natural Resources. All rights reserved.

The University of California prohibits discrimination or harassment of any person on the basis of race, color, national origin, religion, sex, gender identity, pregnancy (including childbirth, and medical conditions related to pregnancy or childbirth), physical or mental disability, medical condition (cancer-related or genetic characteristics), ancestry, marital status, age, sexual orientation, citizenship, or status as a covered veteran (covered veterans are special disabled veterans, recently separated veterans, Vietnam era veterans, or any other veterans who served on active duty during a war or in a campaign or expedition for which a campaign badge has been authorized) in any of its programs or activities. University policy is intended to be consistent with the provisions of applicable State and Federal laws.

Inquiries regarding the University's nondiscrimination policies may be directed to the Affirmative Action/Staff Personnel Services Director, University of California, Agriculture and Natural Resources, 300 Lakeside Drive, 6th Floor, Oakland, CA 94612-3550 (510) 987-0096. For a free catalog of other publications, call (800) 994-8849. For help downloading this publication, call (530) 297-4445.

This publication has been anonymously peer reviewed for technical accuracy by University of California scientists and other qualified professionals. This review process was managed by the ANR Associate Ed7itor for Animal, Avian, Aquaculture, and Veterinary Sciences.

pr-11/05-SB/CR

ISBN 978-1-60107-333-4 